\title{
Marketising private tuition: Representations of tutors' competence, entrepreneurial opportunities, and service legitimation in home tutoring business manuals
}

\begin{tabular}{|c|l|}
\hline Journal: & British Educational Research Journal \\
\hline Manuscript ID & CBER-2019-0030.R1 \\
\hline Manuscript Type: & Original Paper \\
\hline Keywords: & $\begin{array}{l}\text { education markets, supplementary education, shadow education, } \\
\text { intensive parenting }\end{array}$ \\
\hline & $\begin{array}{l}\text { Education researchers have explored the marketisation of schools } \\
\text { resulting from neoliberal education policy, but little attention has been } \\
\text { paid to supplementary education markets. Supplementary education } \\
\text { services, such as private tuition, are delivered outside of school } \\
\text { boundaries but designed to improve performance within it. A small body } \\
\text { of research demonstrates that the private tuition market in the United } \\
\text { Kingdom (UK) and the United States (US) is burgeoning, and that } \\
\text { students' access to this service is differentiated by region, class and } \\
\text { ethnicity. These emerging demand-side analyses are vital, but they } \\
\text { cannot tell us about the educational entrepreneurship that shapes the } \\
\text { supply of private tutoring services. This paper addresses this lacuna } \\
\text { through a discourse analysis of manuals, published as part of the } \\
\text { developing tutoring support industry, that are designed to guide would- } \\
\text { be entrepreneurs through the establishment of a private tuition business. } \\
\text { This analysis excavates manuals' treatment of: tutors' motivation to } \\
\text { work in the sector and their competence to do so; strategies to be } \\
\text { employed in the marketisation of tuition services; and the need to build } \\
\text { trust to ensure business legitimation in an unregulated industry. In } \\
\text { conclusion, the paper sets a new agenda for research into fast } \\
\text { developing supplementary education markets that explores: (i) the } \\
\text { dynamics of this expanding educational workforce of private tutors; (ii) } \\
\text { the ways marketisation addresses and augments parental anxiety about } \\
\text { children's education; and (iii) the need for safeguarding and quality } \\
\text { control in private tuition. }\end{array}$ \\
\hline
\end{tabular}

\section{SCHOLARONE Manuscripts}




\title{
Marketising private tuition: Representations of tutors' competence, entrepreneurial opportunities, and service legitimation in home tutoring business manuals
}

\begin{abstract}
Education researchers have explored the marketisation of schools resulting from neoliberal education policy, but little attention has been paid to supplementary education markets. Supplementary education services, such as private tuition, are delivered outside of school boundaries but designed to improve performance within it. A small body of research demonstrates that the private tuition market in the United Kingdom (UK) and the United States (US) is burgeoning, and that students' access to this service is differentiated by region, class and ethnicity. These emerging demand-side analyses are vital, but they cannot tell us about the educational entrepreneurship that shapes the supply of private tutoring services. This paper addresses this lacuna through a discourse analysis of manuals, published as part of the developing tutoring support industry, that are designed to guide would-be entrepreneurs through the establishment of a private tuition business. This analysis excavates manuals' treatment of: tutors' motivation to work in the sector and their competence to do so; strategies to be employed in the marketisation of tuition services; and the need to build trust to ensure business legitimation in an unregulated industry. In conclusion, the paper sets a new agenda for research into fast developing supplementary education markets that explores: (i) the dynamics of this expanding educational workforce of private tutors; (ii) the ways marketisation addresses and augments parental anxiety about children's education; and (iii) the need for safeguarding and quality control in private tuition.
\end{abstract}

Key words: education markets; supplementary education; shadow education; intensive parenting.

\section{Education markets and the supplementary education industry}

Education is crucial to the economic success of nations and plays a vital role in shaping the life-chances of citizens (Jenson \& Saint-Martin, 2006; Mitchell, 2018). Its elevated importance on the political agenda has seen a policy revolution, and in many neoliberal states this has resulted in the marketisation of provision, with a business ethos being imported into schools and the private sector increasingly involved in the delivery of state education (Ball \& Youdell, 2008; Whitty \& Wisby, 2016). Researchers in education have devoted considerable energy to tracing the thoroughgoing consequences of this marketisation. This includes changes both to the school system (e.g. increased school diversity, parental choice) and to activity within schools (e.g. management cultures, the curriculum, staffing, teacher identities, classroom practices, and student outcomes (Cohen and Lizotte, 2015; Samuelsson \& Lindblad, 2015; Pratt, 2016; Whitty \& Wisby, 2016). The impacts of marketisation have also been felt outside of schools, as parents have responded to the narrowing of the school curriculum, as well as the broader individualisation of risk (Beck \& Beck-Gernsheim, 2002), by promoting rounded child-development through participation in extra-curricular activities, many of which are run on a commercial basis (Holloway and Pimlott-Wilson, 2014; Weiner et al., 2015). 
One aspect of the marketisation of education that has received remarkably little attention is the growth of private tuition. Private tuition is commercially-provided, supplementary education that is designed to help pupils "catch up, keep up, or get ahead of their peers" in their grasp of academic subjects taught in mainstream schools (Choi \& Cho 2016, p.600). In the international context, it is often referred to metaphorically as shadow education for the way it mirrors the formal school system that it is designed to supplement, but, as an often unregulated industry, is shaded from view (Bray, 2017). Globally, it is most highly developed in East Asia where Confucian values (particularly the belief that diligence makes up for deficiency) and high-stakes examinations stimulate demand (Jheng, 2015). The current century, however, has seen a global intensification of shadow education (Aurini et al., 2013; Park et al., 2016). This has been driven by the increasingly competitive, differentiated and credentialised nature of education and the labour market. Rising numbers of parents are responding to the neoliberal injunction that they behave as consumers in education markets by purchasing private tuition, exerting that which is cast as moral agency to calculate what is best for their child and pursue competitive advantage for them (Olmedo \& Wilkins, 2016; Doherty \& Dooley, 2018). Young people too have been responsibilised, and growing numbers respond to the internalised imperative to pass key examinations by willingly participating in private tuition (Entrich, 2015; Pimlott-Wilson, 2017).

This global intensification of private tuition has prompted interest in countries outside of East Asia, and an emerging body of research traces the contingent development of supplementary education in nations which previously had lower usage rates. The UK is an interesting case. In the $18^{\text {th }}$ and early $19^{\text {th }}$ centuries, wealthier families used private tuition as a precursor or alternative to schooling, but the late nineteenth century expansion of school education saw this practice wane. Today, the market in private tuition is burgeoning through its use as a supplement to schooling (Ireson and Rushforth 2011; Song et al., 2013; Pearce et al., 2018; Self-citation, 2019). A recent study of England and Wales reveals that $26.2 \%$ of state-educated children aged 11-16 have now received private tuition at some point in their school career, with $11.3 \%$ of Year 11 pupils using it in the past year. Regression analysis demonstrates that class, region and ethnicity all have a significant independent impact on tuition usage, with wealthier, London-based, and minority ethnic children having greatest access (Self-Citation, 2019). This tuition market is heavily domesticated, with two-thirds of sessions taking place in the tutor's $(23.4 \%)$ or tutee's home $(43.5 \%)$ (Self-citation, 2019$)$; however, permanent tuition businesses and learning centres are a developing part of the market (Tanner et al 2009).

The US has historically had lower levels of private tuition that East Asia, but here too private supplementary education services are flourishing in the twenty-first century (Song et al., 2013; Park et al., 2016). Approximately $12 \%$ of children use private out-of-school instruction in Grades 9-11, a picture which is similar to the UK. However, in the US private supplementary education also takes more diverse forms, including the provision of courses that prime children to sit the SAT, a test used to evaluate applicants to four-year colleges and universities (Buchmann et al., 2010). Nationally representative surveys show that $40 \%$ of American children have used a test preparation course by Grade 12 (Ho et al., 2019). Moreover, the use of hired counsellors to prime children for college application and college preparation camps are also important parts of the supplementary education market here, though these are rarely seen in the UK (Ho et al., 2019). Notwithstanding the availability of additional forms of supplementary education in the US, socio-spatial variations in its use mirror those seen in the UK. Participation is shaped by region (being higher in the Northeast than the Midwest and West), class (favouring wealthier families) and ethnicity (with Asian, Black, and to some extent Hispanic, pupils having proportionally higher usage than their White peers) (Buchmann et al., 2010; Ho et al., 2019).

Such research into socio-spatial inequalities in tuition use in newly developing supplementary education markets is a vital first step; however, tuition use is only one part of 
the picture (Park et al., 2016). This paper drives the field forward by refocusing attention on provision rather than use, deliberately placing the educational entrepreneurship that is central to the marketisation of supplementary education at centre stage. The case study focus is on the developing markets in the UK and the US, where marketisation is itself diverse. It spans large-scale businesses like the Princeton review who provide SAT courses (Buchmann et al., 2010), franchised learning centres such as Kumon who provide group tuition in core subjects (Aurini, 2004), and individual tutors who find business through onand offline agencies and local networks. All three business types warrant greater individual attention. This paper focuses on the final, and most under-researched, section of the market: individual private tutors and their independent tuition businesses. This market is unregulated in both countries; there are no formal professional entry requirements, nor a register of people acting as tutors, a factor which no doubt hampers research. Tanner et al. (2009) is a rare example of research which explores the industry - they show that the market operates to divergent standards in the UK, with fewer than half of agencies requiring their tutors to be qualified teachers. Since this report, we might anticipate that the wider growth of the 'gig' economy in the UK and the US, and increases in the cost of higher education in the UK, might have further stimulated employment in this industry which in 2009 was dominated by part-time, self-employed workers (Tanner et al., 2009; Spreitzer et al., 2017).

There is a lacuna in our knowledge about entrepreneurial opportunities for selfemployment in the supplementary education market (Park et al., 2016), despite research that emphasises the importance of tuition marketisation (Doherty \& Dooley, 2018) and the legitimation of supplementary education businesses (Aurini, 2004). This paper addresses this void through a focus on business guides that seek to instruct individuals who may wish to set themselves up as private tuition businesses. These guides are part of an emergent tuition support industry which offers business advice to start-ups through published guides, workshops and one-to-one training. Business management books more broadly have been shown to provide a framework for thinking about business in its wider context (Kociatkiewicz \& Kostera, 2016). The aim of this paper is to examine how business instruction is articulated in the context of marketised supplementary educational services. Its specific objectives are to consider how business manuals, as a key output of the developing tutoring support industry, represent: (i) the motivations for becoming, and qualities required to be, a competent tutor; (ii) how individuals can marketise their skills to profit from the boom in supplementary education; and (iii) how business legitimacy is established by securing parental trust and performing professional competence in the private tuition industry.

\section{Methodology}

\section{Text selection:}

To provide an insight into the business advice available to aspiring tutors, 19 manuals were analysed that offer advice on establishing one-to-one tuition businesses that support learning in curriculum subjects outside of school. These comprise all paper-based manuals on this subject that were available from a general online retailer and/or an on/offline bookshop. The texts were identified by multiple keyword searches of both businesses' online catalogue systems; the books have not been anonymised as they are published work (see Sources). All the texts are written in English and their mean length is 128 pages. Published between 2007 and 2017, the books include those centred on face-to-face and online tuition, as well as a mixture of the two. Most texts focus on how to establish oneself as an individual tutor, but a minority are concerned with how to found a tuition agency with multiple tutors upon its books. Excluded from the analysis are those texts devoted to the subsequent growth of existing businesses (as the research concerns instruction to new businesses) and those centred on musical education or sports coaching (as these have a subtly different cultural context). 


\section{Social production of texts:}

Researchers must attend to the social production of the texts they study (Waitt, 2010). The majority of guides were written by established tutors diversifying into business advice, but occasionally they are authored by general business writers. As might be anticipated, the books vary in nature. Some texts are extremely well-written and well-rounded guides to business practice in the tutoring industry, based either on individual experience of running a tuition business or insights from those who do. Other texts provide a more personally impassioned and individually insightful introduction to the industry; all of these are written by tutors. The common aim is to induct would-be entrepreneurs into the tuition industry, enabling them to learn from existing business experience rather than their own mistakes. Publishing a business manual can raise the profile of the tutor, adding an additional incomestream to their business; given the one-to-one nature of tuition, tutors are unlikely to facilitate the start-up of direct competitors. Production through niche publishing houses, and selfpublication, is common in this field. This facilitates the availability of a small number of poorer quality texts, not written by tutors, which charge readers for a generic business rather than industry-focused product.

In total, eleven of the texts were published in the US, and 8 in the UK (one UK author [Olubi] chose US publication). The US and UK texts have grown out of different nations, but cultural similarities including underfunded state education, teaching to the test and importance of education in youth transitions produce a similar ethos, even though specific details differ. Differences are drawn out where relevant in the analysis below. As a collection, the texts provide an insight into the business advice offered to aspiring tutors in the UK and US, but one limitation is that they cannot tell us how this is consumed. Future research with tutors that explores this, alongside broader issues, would be beneficial (Ho et al., 2016).

\section{Analytical strategy:}

The texts were subject to a discourse analysis, incorporating both deductive reasoning - in which the texts were scrutinised for issues of interest that had emerged from the literature review - and inductive reasoning - in which dissection of the text allowed for the emergence of themes not anticipated by the researchers (Reichertz, 2014). The process began with a close reading of the texts to familiarise the authors with the data (Waitt, 2010). The texts were then coded using a branching tree system (Bazeley \& Jackson, 2013). The primary branches comprised four overarching research themes. Three of these - becoming a tutor; marketising the service; and securing legitimacy - reflected issues of concern that arose from the literature, but a fourth branch 'other' encapsulated themes that emerged inductively from the text which exceeded this analytical frame (e.g. how to set up a home office; book keeping; tax). These primary themes split into secondary level topics (for example, becoming a tutor encompasses: reasons for becoming a tutor; what tutoring offers; downsides to tutoring; who can tutor; and qualities of a tutor), and second level topics are themselves comprised of tertiary component parts reflecting pre-existing and text-driven points of interest (for example, qualities of the tutor contains organisation, motivation, communication, people skills etc.). These tertiary codes were recorded manually on the texts, and bibliographic details of each code's appearance was recorded in a digital file which drew all sources together. Manual coding was used, despite its time-consuming nature, as this is well suited to paper-based books, but digital logging of codes used ensured rigorous and efficient data management (Basit, 2003). The existence of dominant discourses, as well as counter messages and silences in the text, were then examined and interpreted in the light of wider research to explore how these relate to the educational landscape and socio-economic structures of power (Waitt, 2010). 


\section{Representations of private tuition in business manuals}

\section{Tutors' motivations and competence}

The reasons why individuals might want to become a tutor are commonly addressed in business manuals. The motivations stemming from outside the supplementary education sector centre on individuals' alternative employment opportunities, and this splits potential entrepreneurs into two groups. First, considerable emphasis is placed upon why teachers might want to move into private tuition. Conditions in schools - including the managerial culture, workload, under-funding, test-oriented teaching, challenging classroom management, and teacher burnout that are commonly discussed in the wider educational literature (Ravalier \& Walsh, 2018) - are represented as reasons why people might want to permanently leave school-based teaching. Private tuition is heralded as an opportunity to escape these experiences, whilst maintaining an educational role. Moreover, offering private tuition is seen as an additional opportunity at moments in the teaching professionals' lifecycle, for example suiting young teachers needing extra income, those on career breaks associated with childrearing, and newly-retired teachers.

Second, some manuals highlight why non-teaching professionals might wish to move into private tuition. Their negative experiences in diverse labour markets, or position in an unpaid caring role, are seen to motivate a move into supplementary educational services:

Are you perhaps over fifty years old and feel you're on the scrap heap? Do you sit at home wasting time applying for jobs you will never get; or are you in a thankless, boring, underpaid job, regardless of age? Are you taking a career break to look after a family and would like a challenge? (Woodward, 2010, p.10).

For this group, private tuition offers the opportunity to break out of labour market marginalisation by starting a business of their own. Potential tutors' own precarity thus fuels a rise in educational entrepreneurship as individuals seek to secure an income in a challenging economy (Spreitzer et al., 2017), just as parental fears about children's precarious futures drive their use of this service (Kirby, 2016; Doherty \& Dooley, 2018).

Notwithstanding these two groups' differing external motivations, both are presented as being able to access similar benefits from a private tuition business. The function of these manuals is to help people run a profitable business, and it is not therefore surprising that the potential to "[g]enerate a high income" (Dominus, 2017, p.1) is highlighted as a key attraction of the supplementary education industry. Indeed, as no premises are required the shoestring start-up costs make "the possibilities of earning high revenues" yet more attractive as they come with "comparatively low financial commitment" (Helmy, no date, p.22). This focus on income is, however, set alongside the benefits of autonomy, flexibility and social value. Being one's own boss, and thus having freedom to run a business and tutor using personally-preferred methods is a major attraction, as is the flexibility this provides in terms of control over working hours. Some guides also point out this has its drawbacks (e.g. "no pensions, company subsidized health insurance plans, or paid vacation days"

(DiBartolomeo, 2014, p.8)). However, foregrounding this message would highlight the ongoing insecurity of tutors, like other self-employed, freelance and short-term contract workers in the gig economy (Spreitzer et al., 2017). It is no surprise, therefore, that these manuals, which are designed to encourage entrepreneurship, place greater emphasis on key enticements such as autonomy and flexibility. Moreover, this personal freedom is to be achieved, the guides make clear, through socially-valuable work which allows tutors to make a difference in the lives of children:

There is a sense of fulfilment that's hard to match when a tutor sees a marked improvement in a student, especially one who has been struggling...While tutoring is a way to make money...it's also a way to do something that's constructive, appreciated, and rewarding. (Entrepreneur Press \& Mintzer, 2009, pp.5-6). 
Despite the same benefits, there is a clear tension in the texts about the differential rights of these two potential groups of entrepreneurs to participate in the supplementary education industry. In some manuals, the presumption is that you need to be a qualified teacher, or at the very least a graduate with subject-specific knowledge, in order to tutor. In other manuals, however, the notion that tutoring is the exclusive territory of qualified teaching professionals is firmly disputed (by non-teachers and some teachers alike): "any person can tutor as long as he or she has both the knowledge and skills to be successful" (Holland 2017, p.14). The arguments propounded to justify this position vary from conciliatory to confrontational, but what underpins them is a belief that the ability to tutor is a natural talent. Unlike teaching, which in recent years has seen a swing away from University-based training that combines educational theory and practice, towards the development of teaching craft and technical competence in US and UK schools (Kretchnar \& Zeichner, 2016; Mutton et al., 2017), proficiency in tutoring is seen to stem from personality traits rather than processes of skills' acquisition:

A teaching certificate or Master's Degree is not required to be a tutor...In fact, there are several qualities that are excellent to have before starting your own tutoring business \& they aren't learned in a classroom...Empathy for your students, knowledge of the subject, enthusiasm and overall friendliness are extremely importance qualities in a teacher. I believe that anyone with these qualities will make a VERY successful tutor. (Hammond, no date, pp.7-8).

Although confidently stated, such assertions are clearly designed to encourage selfassurance in the non-teacher reader who is worried about their lack of qualifications in a cultural context where teaching in schools, if not tutoring outside them, is regarded as professional work (Aurini, 2004; Edmond \& Hayler, 2013):

[S]o many people could be tutors but feel as if they're not qualified enough. If you want to tutor, there's pretty much nothing stopping you so you shouldn't feel as if you're inadequate. (Olubi, 2013, p.6).

Tutoring skills, however, are not the only attributes required to run a supplementary education business. Business acumen is also required. It is to this discussion about how to marketise the ability to tutor that the paper now turns.

\section{Sectoral dynamism and individual business opportunity}

The tutoring sector is represented as a substantial and growing sector in many manuals, some of which offer media-sourced statistics and others personal accounts to evidence their argument. Such boosterism might be cynically read as justification for manuals which support new businesses; however, their arguments are clearly reinforced by academic research which charts twenty-first century growth in the industry around the world (Aurini et al., 2013; Park et al., 2016). The causes of this buoyancy in supplementary education are identified in these business texts as both endogenous and exogenous to the formal schooling system. Internally, the growth of test culture, alongside underfunding which limits schools' capacity to provide help targeted at individual student's needs, stokes demand; externally, the growing credentialisation of the labour market further increases parental concern about children's education:

Every parent worries about their child's education and there is an ever increasing need for better qualifications in a highly competitive world. More and more parents are turning to professional tutoring agents to find the help needed for their children in an education system that does not always provide enough support for children's differing needs. A tutoring agency provides a valuable and much-appreciated service. (Stellman \& Howse, 2007, p.3).

The simple explanation presented is that broader socio-economic conditions stimulate demand, so the tuition market supplies. This logic endures even when the economic opportunities parental fears present to tutors are laid bare: 
[I]f people's pain is great enough, then they will pay for a solution...The pain factor in your child falling behind in education is great. This is why there is such a need for it [tutoring]. (Kaminski, 2012, p.31).

Parents are choosing a better life for their children when they invest in tutoring...As a result, tutors are in demand. When demand increases prices go up...As a result, people who tutor can ask for even more money for their services. (Davison-Fujioka, 2011, p.10).

What this narrative eclipses, however, are questions about whether it is the market or the state that ought to meet this demand, its implications for equality, and more fundamentally, given academic concerns over the scholarisation of childhood (Katz, 2017; Mitchell, 2018), whether this demand should be met or tackled in other ways. Thus, apparently simple market logic does heavy ideological work.

Nevertheless, this free-market logic does permeate these texts and readers wishing to marketise their tutoring skills are thus urged to research demand and to concentrate upon what unique service their business will offer to which niche market. This is considered crucial as "[w] hen you create a niche, it keeps your business from struggling with more established tutoring companies and will allow your profit margin to be big early on" (Jordon \& King, 2015, p.6). To do this, the entrepreneur must attune themselves to potential customers' needs: "you need to know who your customers are and what their needs and wants really are" (Nolin, 2011, p.39). In this regard, the manuals suggest locating face-to-face businesses in areas with concentrations of affluent families and focusing initially on a differentiated service in a highly sought-after field (e.g. maths tuition). This advice represents a good business strategy but advising tutors to deliver expensive niche services in wealthier neighbourhoods can only perpetuate existing class-based inequality in access to private tuition (Buchmann et al., 2010; Pearce et al., 2018). Strikingly, the manuals do not reflect on the greater propensity of Black, Asian and minority ethnic families to use tuition in their exhortations to know your market (Ho et al., 209; Self-citation, 2019), suggesting perhaps that targeting wealth is more palatable in business manuals than exploiting minority-ethnic differences.

Having identified their niche service and ideal client, the would-be entrepreneur then needs to advertise for business. In the Australian context, Doherty and Dooley (2018: 562) argue that regular tuition advertising amounts to a 'nudge strategy' which normalises the existence of shadow education and casts its use as a moral and responsible parental choice. In these manuals advertising is portrayed as an initial, and then dynamic, activity as entrepreneurs are advised to adapt to the temporality of the tuition market:

You can imagine that there are certain times of the school year when parents have a heightened awareness of their children's progress at school, and thus are increasingly motivated to take action. I recommend building your marketing plan around these occasions. (Lewis, 2010, p.125).

Be aware... of schools near you that have just had an undesirable or critical OFSTED [school inspection] report or particularly poor exam results. You then need to target parents in that area by placing leaflets in shops or venues near that school. (Woodward, 2010, p.30).

In suggesting that advertising target opportune moments of parental concern, these manuals belie the notion that the tuition industry simply fulfils demand, demonstrating that parental uneasiness can also be stoked by a sector keen to drive business growth. This exemplifies why the supplementary education sector is 'considered parasitic by some' as it 'actively cultivates[s] the anxieties it purports to assuage' (Doherty and Dooley 2018, p.562). Intriguingly, in this focus on advertising, current customers are regarded as the best sources of future business for both offline and online businesses. Existing clients not only reuse the service with subsequent children, their recommendations - whether word-of-mouth in the local community, or digitally-mediated to a wider public (e.g. through Linkedln validations) are a crucial source of future business. This is significant as it points to the importance of 
trust in this unregulated sector (Kirby, 2016; Bray, 2017); this is an issue which the subsequent section on business legitimation considers in more detail.

\section{Legitimating service provision: securing trust and performing professionalism}

Budding private tutors can advertise for business but, in an industry for which there are no formal entry requirements (Kirby, 2016; Bray, 2017), they require strategies to convince potential clients that their service is a valuable one. The manuals cast parents as the clients, undervaluing the role played by young people in shaping tuition usage (Entrich, 2015; Selfcitation, 2019). Tutors who are either qualified teachers, or employ such through their agency, are advised to advertise this fact, and use it in their face-to-face sales pitch to parents, as they are recognised as education professionals (Aurini, 2004; Edmond \& Hayler, 2013). Those who are not trained teachers are reassured that parents rarely ask directly, but are nevertheless given guidance on how to market their previous experience to emphasise their capabilities. One self-described 'controversial and outspoken' (Woodward, 2010, p.10) author goes further, and combines critique of teacher competence with the provision of reassuring references:

In over ten years of being a private home tutor I have been asked if I was a qualified teacher only three or four times. I always reply politely, "No, I am not, but if you are happy with teachers who are qualified and the school, why are your ringing me?" I offer them references and testimonials from satisfied parents and they are perfectly happy. (Woodward, 2010, p.14).

This rejection of teacher competence may make uncomfortable reading for education professionals, but wider studies suggest that some parents place greater emphasis on subject knowledge than pedagogical competence, happily employing university or school students as tutors (Bray and Kobakhidze, 2014).

Teaching qualifications, successful private-tutoring practice and/or subject-specific knowledge are important in securing parental trust, but alone they are not enough. Securing legitimacy as a private tutoring business is not cast as a one-step process in these manuals, but as multi-stranded activity (Aurini, 2004). The business' online presence is one crucial facet of this. At its most basic, the manuals argue a well-presented website "adds legitimacy to your business" (Paulsen \& Paulsen, 2006, pp.6\&21), enhancing "your level of professionalism and ability to charge on the higher end of the scale" (DiBartolomeo, 2014, p.18). This digital presence presents the image parents would expect from experts, notwithstanding the fact that tutors may not have qualifications (Kirby, 2016). Increasingly, advice on search engine optimisation is given, not only to attract traffic to the site - with the "2nd page of Google" being described as "the best place to hide a tree" (O'Neill, 2017, p.68) - but also because appearing early in search results builds trust, with most internet users relying heavily on rankings to guide choices (Kammerer \& Gerjets, 2014). Moreover, website content, and tutors' social media presence, is portrayed as an opportunity to build further trust by portraying authenticity and credibility:

$[R]$ egister your own domain name...I recommend choosing your name...parents are impressed by this...[it] presents you as a real person and professional, and the parent will feel more comfortable after reading about your background. (Hammond, no date, p.19).

[G]et on Linkedln...Your experience working as a teacher will be here to begin building credibility...Y You will want to create a business page on Facebook and invite all of your friends to like you. This again will show credibility... If you have a small following people may put their guard up and not trust you. (Kaminski. 2012, pp.86, 88).

Pricing is also a crucial way in which tutors can secure trust in their service. Št'astný (2017) argues that, in the Czech Republic, tuition pricing reflects tutors' qualifications and experience, as well as regional and subject-specific market conditions (and an entrenched 
gender pay gap). The central message running through the manuals partially reflects this logic, as it suggests that tutors recognise their own value and be aware of market conditions. However, this does not result in a simple lesson about the relation between tutor supply (e.g. in terms of qualifications), demand and pricing. Rather, the argument seen across numerous manuals is that pricing shapes demand by acting as a proxy measure of service quality. Set the price too low, parents will assume the service is poor and avoid it; set it higher and you will attract more customers:

Many tutors fail because they think they need to come in lower than others in order to gain clients. Answer this, would you purchase a BMW for $\$ 700$. It would make you think something must be wrong with it. This is the same way clients think about tutors. If it is too low, they must be a beginner, not experienced, and desperately needing cash. (Jordan \& King, 2015, pp.10-11).

The fact that a higher price can increase the attractiveness of a product when quality is difficult to evaluate is recognised in the economics literature, but it can also raise consumer expectations affecting satisfaction (Gneezy et al., 2014). In this context, some manuals advise that tutors can justify higher charges, and resist attempts to haggle, by explicitly articulating how investment in tuition pays dividends (e.g. entrance to good state school saves private-school fees; good school results open access to better universities and job prospects). In this way, by playing to parental fears about the quality of their children's education, and its vital importance in shaping their futures, tutors can articulate their own value, meaning "people realise that you're worth every penny and more" (Olubi, 2013, p.60).

Entrepreneurs' first personal contact with parents, and engagement with children, is a vital opportunity to embed business legitimacy. The business guides emphasise the importance of a welcome letter/email, capable telephone manner, professional answerphone message, and prompt response to exude both competence and kindness. This ethos of efficient but caring customer service is carried through into recommendations about tutors' first meeting with parents. The undergirding message is that new business owners need to listen, and be seen to be listening, to what parents are saying. In a business that is underpinned by the growth of intensive parenting strategies (Craig et al., 2014), and where parental efforts to engage with markets to secure the best for their children is cast as moral agency (Olmedo \& Wilkins, 2016), tutoring businesses must mould themselves to parental values and aspirations (Aurini, 2004), demonstrating that they understand parents' concerns and children's needs. Following their assessment of a tutee's requirements, the new business owner is then encouraged to build parents' confidence in the tutor's ability to make a difference:

Thank the parent and assure them that your [their] children will improve with you as their tutor (Davison-Fujioka, 2011, p.61).

Writing specific goals is a crucial and nonnegotiable part of your business's "product line." It's also an opportunity to show off your pedagogical expertise and demonstrate proactively that you can be trusted to accomplish what you set out to do. (Lewis, 2010, p.71).

Although the central emphasis is on parents in these manuals, tutors are also exhorted to ensure children are willing to attend sessions. The manuals are silent on the subject of children's voice or rights; instead they suggest securing buy-in by connecting with children though common interests and rapport-building techniques to ensure business success: None of these ways of connecting with students actually takes a lot of time, so the time that you invest in them will have big dividends for you. You will come off as personable and likeable, Guess what? People like to do business with people they like, know and trust. (Kaminski, 2012, p.132).

Business manuals also direct entrepreneurs towards self-conscious performances of professionalism in tuition delivery. General professionalism - including: reliability and punctuality; suitable attire and personal hygiene; neutral home decor; undisturbed tuition sessions - is widely encouraged as it will shape clients' perceptions of the tutoring business, 
reinforcing business legitimacy in a sector bereft of regulation and defined standards (Kirby, 2016). Education-related professionalism (e.g. awareness of current developments; interest in children's teachers and reports; avoiding critique of other educators) is also important to some. A minority go further and, in a move first seen in franchised learning centres (Aurini, 2004), encourage tutors to enhance their image as a caring professional through community engagement, a move which echoes a moral commitment to social improvement that is common in characterisations of teachers' professional status:

[I]n order to gain their trust, you should strive to be a good citizen of your community...If people see that you're a good person worthy of their trust, they're more like to refer your business to their friends and family (Nollin, 2011, p.92). By contrast, there is surprisingly little in the manuals on safeguarding. One US author reminds readers that "[t]here is no reason to touch a child in a tutoring session for any reason" (Dominus, 2017, p.19) and suggests insisting on parental presence. Two UK authors raise the issue of criminal records checks (a requirement for UK teachers), but while certification is recognised as an opportunity to display professionalism, one text advises caution in committing tutor agencies to checks "given the high costs of this procedure and the length of time it takes" (Stellman and Howse, 2007. p.24). None of the manuals prepares tutors for other safeguarding issues that they might face.

Finally, the manuals emphasise the importance of feedback to parents. As clients but not recipiences of the services, parents need to be shown the ongoing value of the service to their children:

A tutor should never live by the motto, "No news is good news."... If parents don't hear from you on a regular basis, you risk having them make the assumption that nothing positive is being accomplished in the tutoring sessions. Why should they pay you for tutoring sessions when no apparent progress is being made? (Lewis, 2010, p.89).

As a business owner, you need to stress to your tutors that they not only have to do a good job as a tutor, but make it clear that the next session will move the process forward...By selling the idea that there is more work to be done, you show the student and parent that there is an ongoing plan and a reason to keep returning. (Entrepreneur Press \& Mintzer, 2009, p.128).

In this respect, the manuals suggest that parents, who have been responsibilised for their children's education (Olmedo \& Wilkins, 2016), should be continuously nudged (Doherty \& Dooley, 2018) - by news of what has been achieved, and pointed reminders about what is still required - into ongoing use of private tuition. This emphasis placed in manuals on cultivating existing customers is good business sense, but it is also one way in which the industry can fuel, as well as respond to, demand for private tuition.

\section{Conclusions}

Marketisation has been an important tool in neoliberal educational restructuring. Previous research illustrates its critical impact in redefining the school system, and an ever-growing body of work unearths the ways practices within schools have been reshaped by business logics (Ball \& Youdell, 2008; Pratt, 2016). This paper reveals how the logics of marketisation extend beyond the school gates into the supplementary education sector. There is a nascent literature which explores the outcomes of supplementary education in newly expanding markets, most notably in terms of differential access to private tuition by region, class and ethnicity (Pearce 2018; Ho et al., 2019; Self-citation, 2019). This paper, however, takes an original approach in focusing on the supply side of this industry, and explores how business manuals coach potential tutors who intend to found supplementary education businesses. This focus on supply, rather than simply access, forges a new agenda for researchers in education. 
Firstly, the discursive representation of tutors' motivations and competence raises interesting questions about tutors as an expanding educational workforce. There has been considerable debate in education policy and research about how best to train teachers, and in recent years the pendulum has swung away from the dominance of higher education institutions, which are seen to provide research-based learning, towards schools, which can provide practical preparation in a context where teaching is increasing presented as a craft or technical skill (Edmond \& Hayler, 2013; Kretchmar \& Zeichner, 2016; Mutton et al., 2017). To this picture we now need to add the figure of the tutor. There are no minimum entry requirements to work in the tuition industry, and while many tutors are trained teachers, many are not (Kirby, 2016; Štastný, 2017). Indeed, the underpinning argument of some manuals is that qualifications and training are not required; rather, the ability to tutor is a talent that some people simply possess. In this way, these manuals bypass the need for academic learning about educational theory, and the need for supervised practise, seen in teaching qualifications (Kretchmar \& Zeichner, 2016; Mutton et al., 2017), while nevertheless representing tutors as professional workers doing socially-valued work. The unfettered private tuition market has produced an expanding educational workforce who are often driven to seek work in this flourishing sector by their own economic precarity, and who without any mandatory training are involved in the education of school-aged children in the UK and the US. This raises pressing questions for future research about tutors' professional identities, training levels and educational practices, as well as their own financial security. More broadly, we also need to consider the implications of the unequal shadow education market for the delivery of, and measurements of effectiveness in, state education.

Secondly, the marketisation of tutors' skills demonstrates the intersection of wider socio-economic forces and market rationality in stimulating the supplementary education industry. The growing importance of education in knowledge economies means educational credentials can be necessary, if not sufficient, to ensure youth transitions from education into employment (Pimlott-Wilson, 2017; Mitchell, 2018). In a context where school systems are stretched and sufficient resources are not available to meet the needs of all learners (Ravalier \& Walsh, 2018), parents who under neoliberal models of governance are increasingly held responsible for child outcomes are likely to turn to the market for help if they are financially able to do so (Olmedo \& Wilkins, 2016; Pearce et al., 2018). Their children who have been schooled in the need for academic success are likely to agree with them (Entrich, 2015). This confluence of socio-economic factors creates nascent demand for private tuition and as this paper demonstrates, educational entrepreneurs are then wellgroomed by business manuals about how to fashion their product to fulfil this need. Indeed, as some of the marketing tactics recommended in these guides lay bare, businesses may not only market a service designed to address parental concerns, they also exploit these fears to stoke demand, enabling them to attract and retain more customers. Exploring the importance of socio-economic change, as well the ways this is capitalised upon by the market, is crucial if we are to understand this burgeoning education sector.

Finally, the efforts businesses put into securing initial parental trust and performing professionalism at each stage of the service to maintain business legitimacy highlights the profound lack of regulation or quality control in this market. Teachers in state schools receive considerable training and experience constant monitoring (Mutton et al., 2017), but in the UK and US the private supplementary education industry is devoid of regulation and quality control (Kirby, 2016; Bray 2017). There are indeed many tuition businesses that are highly valued by their clients (Self-citation, 2019). Furthermore, many practices suggested in these manuals are entirely sensible, but they are not in themselves sufficient to ensure quality control. There is an urgent need to shine a light on this market that exists in the shadows, well away from state scrutiny. Whereas state schooling is a heavily monitored service that has been opened up to market logics, supplementary education reflects the operation of market logics, yet remains unaffected by any regulatory regime (Ball \& Youdell, 2008; Bray, 2017). It is in urgent need of oversight. At its most basic, intervention is required 
to ensure safeguarding (e.g. tutors in the UK do not currently need a DBS certificate), but, longer-term, parents and children also need to understand what quality of service they are accessing. Much of the marketisation agenda aimed at schools has produced metrics that theoretically facilitate informed consumer behaviour (Olmedo \& Wilkins, 2016). It is perverse that in the supplementary education market that similar information is not available. Moreover, going forward it is vital that we pair growing interest in socio-spatially unequal access to private tuition (Pearce et al., 2018; Ho et al., 2019) with greater attention to the impact that use of supplementary education has on parents and children (Park et al., 2016). This will ensure we not only consider the reproduction of educational inequality through the market, but also explore this industry's implications for childhood and family life.

\section{Acknowledgements}

Anonymised.

\section{Sources}

1. Davison-Fujioka, K. (2011) Tutoring: complete home business guide (USA, Selfpublished) ISBN 9781463566234

2. DiBartolomeo, M. (2014) Make tutoring your career (USA, Self-published) ISBN 9780692331705

3. Dominus, T. (2017) Tutor your way to money \& fun (USA, Self-published) ISBN 9781548005832

4. Entrepreneur Press and Mintzer, R. (2009) Start your own tutoring and test prep business (Madison, WI, Jere L Calmes) ISBN 97815999183473

5. Hammond, K. (no date) Tutor and grow rich (USA, Self-published) ISBN 9781434890597

6. Helmy, M. (no date) Turning tuition into a business (Great Britain, Amazon) ISBN 9781523606672

7. Holland, A. (2017) Starting \& operating an online tutoring business (Second Edition) (Phoenix, Az, iGlobal Educational Services) ISBN 9781944346577

8. Johnson, T.K. (2015) How to build a tutoring business (USA, Self-published) ISBN 9781519564733

9. Jordan, L.T.L. and King, W. (2015) Tutor 2 tutor: a guide of earning wealth through tutoring (Great Britain, Amazon) ISBN 9781507737323

10. Kaminski, J.B. (2012) Job security for life in teaching: how to become an online tutor (Great Britain, Amazon) ISBN 9780988930117

11. Lewis, B.A. (2010) How to start a home-based tutoring business (Guildford, Connecticut, Globe Pequot Press) ISBN 9780762754328

12. Mahoney, B. (2016) Private Tutor Business Tutoring Book (USA, Self-published) ISBN 9781539049166

13. Nollin, G. (2011) How to set up a tutoring business (Great Britain, Amazon) ISBN 9781479230877

14. O'Neill, D. (2017) The tutoring small business book that will make you money right now (USA, Self-published) ISBN 9781717269201

15. Olubi, V. (2013) Become a private tutor (USA, Self-published) ISBN 9781499398892

16. Paulsen, M.C. and Paulsen, J.L. (2006) Advanced tutoring systems (Milton Keynes, Lightning Source UK) ISBN 9781430325185

17. Stellman, G. and Howse, V. (2007) How to start and run your own home tutoring business (Oxford, How to Books) ISBN 9781845281786

18. Turner, L. (no date) How to start and run a profitable home tutoring business (Great Britain, Amazon) ISBN 9781549748912

19. Woodward, G. (2010) How to start a business as private tutor (Lancashire, Universe of Learning Ltd) ISBN 9781849370295 


\section{References}

Aurini, J. (2004) Educational entrepreneurialism in the private tutoring industry: balancing profitability with the humanistic face of schooling, Canadian Review of Sociology and Anthropology, 41(4), 475-491.

Aurini, J., Davies, S. \& Dierkes, J. (2013) Out of the shadows: the global intensification of supplementary education (Bingley, Emerald Books).

Ball, S. J. \& Youdell, D. (2008) Hidden privatisation in public education (Institute of Education, London).

Basit, T. (2003) Manual or electronic? The role of coding in qualitative data analysis, Educatioanl Research 45(2), 143-154.

Bazeley, P. \& Jackson, K. (2013) Qualitative Data Analysis with NVIVO (London, Sage).

Beck, U. \& Beck-Gernsheim, E. (2002) Individualization: Institutionalized Individualism and its Social and Policitcal Consequences. (London, Sage).

Bray, M. (2017) Schooling and its supplements: changing global patterns and implications for comparative education, Comparative Education Review, 61(3), 469-491.

Bray, M. \& Kobakhidze, M.N. (2014) The global spread of shadow education: supporting or undermining qualities of education? in D.B. Napier Qualities of education in a globalised world (Rotterdam, SensePublishers).

Buchmann, C., Condron, D.J. \& Roscigno, V.J. (2010) Shadow education, American style: test preparation, the SAT and college enrolment, Social Forces, 89(2), 435-462

Choi, J. \& Cho, R. M. (2016) Evaluating the effects of governmental regulations on South Korean private cram schools, Asia Pacific Journal of Education, 36(4), 599-621.

Cohen, D. \& Lizotte, C, (2015) Teaching the market: fostering consent to education markets in the United States, Environment and Planning A, 47(9), 1824-1841.

Craig, L., Powel, A. \& Smyth, C. (2014) Towards intensive parenting? Changes in the composition and determinants of mothers' and fathers' time with children 1992-2006', The British Journal of Sociology, 65(3), pp. 555-579.

Doherty, C. \& Dooley, K. (2018) Responsibilising parents: the nudge towards shadow tutoring, British Journal of Sociology of Education, 39(4), 551-566.

Edmond, N. \& Hayler, M. (2013) On either side of the teracher: perspectives on professionalism in education, Journal of Education for Teaching, 39(2), 209-221.

Entrich, S.R. (2015) The decision for shadow education in Japan: students' choice or parents' pressure', Social Science Japan Journal, 18(2), 193-216.

Gneezy, A., Gneezy, U. \& Lauga, D.O. (2014) A Reference-Dependent Model of the PriceQuality Heuristic, Journal of Marketing Research, 51(2), 153-164.

Ho, P., Park, H. \& Kao, G. (2019) Racial and ethnic differences in student participation in private supplementary education activities, Research in Social Stratification and Mobility, 59(Feb), 46-59. 
Holloway, S.L. \& Pimlott-Wilson, H. (2014) Enriching children, institutionalizing childhood?: geographies of play, extra-curricular activities, and parenting in England, Annals of the Association of American Geographers, 104(3), 613-27.

Ireson, J. \& Rushforth, K. (2011) Private tutoring at transition points in the English education system: its nature, extent and purpose, Research Papers in Education, 26(1), 1-19.

Jenson, J. \& Saint-Martin, D. (2006) Building blocks for a new social architecture: The LEGO(TM) paradigm of an active society, Policy and Politics, 34(3), 429-451.

Jheng, Y.-J. (2015) The influence of private tutoring on middle-class students' use of in-class time in formal schools in Taiwan, International Journal of Educational Development, 40(January), 1-8.

Kammerer, Y.\& Gerjets, P. (2014) The Role of Search Result Position and Source Trustworthiness in the Selection of Web Search Results When Using a List or a Grid Interface, International Journal of Human-Computer Interaction, 30(3), 177-191.

Katz, C. (2017) The Angel of Geography: Superman, Tiger Mother, aspiration management, and the child as waste*. Progress in Human Geography, 42(5), 723-740.

Kirby, P. (2016) Shadow schooling: private tuition and social mobility in the UK (London, The Sutton Trust).

Kociatkiewicz, J. \& Kostera, M. (2016) Grand plots of management bestsellers: Learning from narrative and thematic coherence, Management Learning, 47(3), 324-342.

Kretchmar, K. \& Zeichner, K. (2016) Techer prep 3.0: a vision for teacher education to impact social transformation, Journal of Educaiton for Teaching, 42(2), 417-433.

Mitchell, K. (2018) Making workers: radical geographies of education (London, Pluto Press).

Mutton, T., Burn, K. \& Menter, I. (2017) Deconstructing the Carter Review: competing conceptions of quality in England's "school-led" system of initial teacher education, Journal of Education Policy, 32(1), 14-33.

Olmedo, A. \& Wilkins, A. (2016) Governing through parents: a genealogical enquiry of education policy and the construction of neoliberal subjectivities in England, Discourse: Studies in the Cultural Politics of Education, 38(4), 573-589.

Park, H., Buchmann, C., Choi, J and Merry, J.J. (2016) Learning beyound the school walls: trends and implications, Annual Review of Sociology 42, 231-52.

Pearce, S., Power, S. \& Taylor, C. (2018) Private tutoring in Wales: patterns of private investment and public provision, Research Papers in Education, 33(1), 113-126.

Pimlott-Wilson, H. (2017) Individualising the future: the emotional geographies of neoliberal governance in young peoples' aspirations, Area, 49(3), 288-295.

Pratt, N. (2016) Neoliberalism and the (internal) marketisation of primary school assessment in England, British Educational Research Journal, 42(5), 890-905.

Reichertz, J. (2014) Induction, deduction, abduction, in U. Flick (ed) The Sage handbook of qualitative methods (London, Sage).

Ravalier, J.M. \& Walsh, J. (2018) Working conditions and stress in the English education 
system, Occupational Medicine, 68(2), 129-134.

Samuelsson, K. \& Lindblad, S. (2015) School management, cultures of teaching and student outcomes: comparing the cases of Finland and Sweden, Teaching and Teacher Education. 49(July), 168-177.

Song, K.-O., Par, H-J. \& Sang, K-A, (2013) A cross-national analysis of the student- and school-level factors affecting the demand for private tutoring, Asia Pacific Education Review 14(2), 125-139.

Spreitzer, G.M., Cameron, L. \& Garrett, L. (2017) Alternative work arrangements: two images of the new world of work, Annual Review of Organizational Psycholgy and Organizational Behavior, 4, 473-99.

Št'astný, V. (2017) Private tutoring lessons supply: insights from online advertising in the Czech Republic Compare: A Journal of Comparative and Internatioanl Education, 47(4), 561-579.

Tanner, E., Day, N., Tennant, R., Turczuk, O., Ireson, J., Rushforth, K. \& Smith, K. (2009) Private tuition in England Research Brief DCSF-RG081. Available online at:

http://natcen.ac.uk/media/26747/private-tuition-england.pdf (accessed 23 November 2018).

Waitt, G. (2010) Doing Foucauldian discourse analysis - revealing social realities, in I. Hay (ed) Qualitative research methods in human geogrpahy (Oxford, Oxford University Press).

Weininger, E.B., Lareau, A. \& Conley, D. (2015) What money doesn't buy: class resources and children's participation in organsied extracurricular activities, Social Forces, 94(2), 479503.

Whitty, G. \& Wisby, E. (2016) Education in England - a testbed for network governance?, Oxford Review of Education, 42(3), 316-329. 